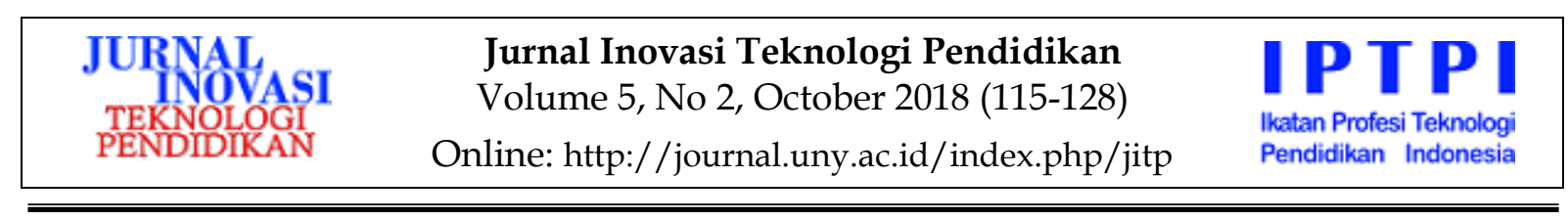

\title{
PENGEMBANGAN MULTIMEDIA PERMAINAN INTERAKTIF PEMBELAJARAN BERHITUNG BAGI ANAK DISKALKULIA USIA PRASEKOLAH
}

\author{
Nusuki Syari'ati Fathimah ${ }^{1}$ *, Ishartiwi 1 \\ 1Universitas Negeri Yogyakarta \\ 1J1. Colombo No. 1, Depok, Sleman 55281, Yogyakarta, Indonesia \\ * Corresponding Author. Email: nuki.fathimah@gmail.com
}

\begin{abstract}
Abstrak
Penelitian ini bertujuan untuk menghasilkan multimedia permainan interaktif pembelajaran berhitung yang layak bagi anak diskalkulia usia prasekolah. Penelitian pengembangan ini mengacu pada langkah pengembangan multimedia Alessi \& Trollip mencakup tiga fase pengembangan yang meliputi perencanaan, perancangan, dan pengembangan. Subjek uji coba dalam penelitian ini yaitu dua orang ahli media, dua orang ahli matematika, dan sembilan anak diskalkulia usia prasekolah. Hasil penelitian berupa produk multimedia permainan interaktif pembelajaran berhitung bagi anak diskalkulia usia prasekolah berupa permainan puzzle dan logika yang dikemas dalam bentuk compact disc (CD) dengan menggunakan software Adobe Flash CS3. Multimedia permainan interaktif terdiri dari dua area permainan, yaitu area visual-spasial yang mencakup permainan geometri, klasifikasi, dan simbolisasi dan area sekuensial yang mencakup permainan prosedur, korespondensi, dan bilangan. Multimedia permainan interaktif dinilai sangat layak berdasarkan hasil penilaian ahli media $88,33 \%$ dan ahli materi $91,6 \%$ serta berdasarkan hasil penilaian respon pengguna $85,18 \%$.
\end{abstract}

Kata kunci: multimedia permainan, berhitung, diskalkulia, prasekolah

\section{DEVELOPING INTERACTIVE MULTIMEDIA GAMES OF MATHEMATICS TEACHING TO PRESCHOOL DYSCALCULIC CHILDREN}

\section{Abstract}

This research aimed to develop interactive multimedia games of mathematics learning that was eligible for preschool dyscalculic children. This developmental study refered to the multimedia development phase suggested by Alessi \& Trollip consisting of: planning, design, and development. The testing subjects consisted of two media experts, two mathematics experts, and nine preschool dyscalculia children. The results of the study was interactive multimedia games of mathematics learning for preschool dyscalculic chlidren in the form of puzzles and logic games packaged in a compact disc (CD) form using the Adobe Flash CS3 software. The interactive multimedia games had two game areas, consisting of visual-spatial area that consisted of geometry, classification, and symbolization games and sequential area that consisted of procedure, correspondence, and number games. The interactive multimedia games were considered very eligible based on the results from the media experts $88.33 \%$ and from the subject matter experts $91.6 \%$ and based on the results from user's responses $85.18 \%$.

Keywords: multimedia games, mathematic, dyscalculia, preschool

Permalink/DOI: http://dx.doi.org/10.21831/jitp.v5i2.15541 


\section{Pendahuluan}

Pemahaman konsep matematika yang baik sejak dini akan mempengaruhi kemampuan matematika di tingkat selanjutnya. Menurut Powell \& Ray (2012, p. 148) penting sekali membantu anak usia prasekolah mengembangkan pemahaman konseptual yang kuat dalam matematika. Berdasarkan tahap perkembangannya anak usia prasekolah sudah bisa mengenal angka. Anak usia 3 tahun minimal sudah dapat menghitung 3 objek benda (Triharso, 2013, p. 33).

Namun demikian, ada anak yang perkembangannya lebih lambat dari usia seharusnya, yaitu anak yang memiliki kesulitan belajar terlebih lagi kesulitan belajar spesifik. Anak dengan kesulitan belajar spesifik memiliki kecerdasan yang normal, namun memiliki masalah dalam satu atau beberapa area belajar. Menurut Boyse (2012), anak dengan kesulitan belajar spesifik memiliki otak yang belajar dengan cara berbeda karena perbedaan dari struktur atau fungsi otak. Kesulitan belajar spesifik ini mencakup disleksia (kesulitan berbahasa), disgrafia (kesulitan menulis), dan diskalkulia (kesulitan menghitung) (Subini, 2011, p. 51).

Anak diskalkulia memiliki masalah dalam wujud kesulitan membedakan angka, simbol-simbol serta bangun-bangun ruang (kemampuan persepsi visual yang buruk), tidak sanggup mengingat dalil-dalil matematis (ingatan yang buruk), menulis angka yang tidak terbaca atau dalam ukuran kecil (kelemahan fungsi motorik), dan tidak memahami makna simbol-simbol matematis (pemahaman yang lemah terhadap istilah-istilah matematis) (Wood, 2009, p. 75). Chinn \& Ashcroft (2007, p. 17) mengungkapkan area potensial kesulitan belajar matematika, yaitu (a) directional confusion, (b) sequencing problem, (c) visual difficulties, (d) spatial awareness, (e) short-term and working memory, (f) long-term memory, (g) speed of working, dan (h) the languages of mathematics.

Karakteristik anak diskalkulia yang memiliki kekurangan motivasi karena ke- gagalan yang seringkali dialaminya, kurangnya perhatian selama proses pembelajaran, ketidakmampuan melakukan generalisasi, kesulitan dalam pemrosesan informasi, dan masalah dalam problem-solving dan keahlian berpikir (Smith \& Luckasson, 1995, p. 264). Karakteristik belajar tersebut dapat mempengaruhi kualitas belajar anak diskalkulia dalam menyelesaikan permasalahan matematika.

Bagi anak diskalkulia, intervensi (melakukan sesuatu untuk merubah suatu kondisi) lebih dini akan membantu anak lebih mudah menghadapi kesulitannya. Pemahaman yang baik mengenai konsep matematika di usia dini akan membantu anak lebih mudah memahami konsep matematika di tingkat selanjutnya. Dalam pembelajaran matematika yang abstrak diperlukan alat bantu berupa media atau alat peraga yang dapat memperjelas materi yang akan disampaikan sehingga lebih mudah dipahami oleh anak (Heruman, 2013, p. 2).

Berdasarkan hasil observasi, media yang digunakan di dalam kelas masih terbatas dan hanya berupa media gambar saja atau alat peraga yang digunakan untuk beberapa materi saja. Penggunaan media berbasis komputer dalam penelitian Bardi \& Jailani (2015, p. 59) dapat menarik minat peserta didik dan menambah motivasi belajar matematika. Mutimedia yang mengintegrasikan semua elemen (audio, video, grafis, teks, dan animasi) dapat memberikan keuntungan bagi pengguna dibandingkan elemen media secara sendiri-sendiri. Multimedia yang menggabungkan berbagai elemen dapat membantu anak untuk mengkonstruksi pengetahuannya sendiri (Putra \& Ishartiwi, 2015, p. 177).

Menurut Reddi \& Mishra (2003, p. 4) multimedia menjadikan pembelajaran lebih ramah dan menyenangkan tanpa akan takut kegagalan sehingga akan membantu anak untuk lebih termotivasi. Smaldino, Lowther, \& Russel (2014, p. 201) menyatakan bahwa multimedia juga memiliki keuntungan berikut (1) interaktif, membutuhkan partisipasi peserta didik yang dapat membuat peserta didik lebih memusatkan perha- 
tian, (2) individualisasi, peserta didik dapat belajar sesuai kecepatan masing-masing, (3) kebutuhan khusus, multimedia efektif untuk anak dengan kesulitan belajar sehingga dapat mengakomodasi kebutuhan mereka, (4) pengelolaan informasi, multimedia dapat mengelola berbagai tipe informasi yang dapat membantu peserta didik memproses informasi dalam pembelajaran, dan (5) pengalaman multisensori yang dapat memberikan pengalaman belajar yang berbeda bagi peserta didik.

Anak diskalulia usia prasekolah merupakan saat anak-anak masih senang bermain. Menurut Casey, Reeves, \& Conner (2012, p. 135), bermain mendukung anak dalam perkembangan kognitif sehingga membantu anak dalam mencapai tingkat selanjutnya. Multimedia model permainan merupakan salah satu bentuk model yang didesain untuk membangkitkan kegembiraan peserta didik sehingga dapat memungkinkan tersimpannya konsep lebih lama, pengetahuan atau keterampilan yang diharapkan dapat diperoleh dari permainan tersebut (Wijaya, 2014).

Multimedia permainan menurut Alessi \& Trollip (2001, p. 271) memiliki keuntungan untuk lingkungan belajar, yaitu permainan dapat secara efektif memotivasi peserta didik. Hal ini sejalan dengan penelitian Mutlu \& Akgun (2017, p. 119) bahwa penggunaan Computer Assissted Instruction pada anak diskalkulia meningkatkan keterampilan bilangan anak dan meningkatkan kecepatan menjawab soal. Berdasarkan penelitian Widyatmojo \& Muhtadi (2017, p. 48), multimedia berbasis permainan memiliki daya tarik bagi anak dan meningkatkan interaktivitas yang dapat merangsang pembelajaran.

Beberapa jenis permainan yang populer menurut Alessi \& Trollip (2001, p. 271), yaitu adventure games, business games, board games, combat games, logic games and puzzle, dan word games. Multimedia permainan interaktif pembelajaran berhitung ini merupakan jenis permainan puzzle dan logika, karena anak harus mampu meng- gunakan pemecahan masalah logis untuk berhasil menyelesaikan permainan.

Multimedia permainan interaktif untuk pembelajaran dipercaya dapat meningkatkan proses pembelajaran, baik dalam istilah behavior, kognitif, dan konstruktivistik (Casey, Reeves, \& Conner, 2012, p. 135). Multimedia permainan menurut Alessi \& Trollip (2001, p. 277) harus memuat faktor-faktor umum berikut (1) tujuan, (2) peraturan, (3) kompetisi, (4) tantangan, (5) fantasi, (6) keamanan, dan (7) hiburan.

Pengembangan multimedia yang dapat memenuhi kebutuhan peserta didik dikaji dalam bidang ilmu teknologi pendidikan. Menurut (Januszewski \& Molenda (2008, p. 1) teknologi pendidikan merupakan "the study and ethical practice of facilitating learning and imporving performance by creating, using, managing appropriate technological processes and resources". Berdasarkan pengertian tersebut, teknologi pendidikan berperan dalam memfasilitasi pembelajaran dan meningkatkan kinerja dengan membuat, menggunakan, dan mengelola proses dan sumber teknologi yang sesuai.

Teknologi pendidikan perlu dibahas secara terus menerus karena adanya kebutuhan nyata yang mendukung pertumbuhan dan perkembangannya. Salah satunya yaitu penyempurnaan sistem pendidikan dengan penelitian dan pengembangan (Abdulhak \& Darmawan, 2013, p. 109). Dalam teknologi pendidikan, hubungan antarkawasan bersifat sinergistik sehingga walaupun pengembangan multimedia permainan interaktif berfokus pada kawasan pengembangan atau cakupan dari kawasan tersebut, namun dapat menarik manfaat teori dan praktik dari kawasan yang lain. Oleh karena itu, pengembangan multimedia permainan interaktif ini turut melibatkan kawasan desain, pengelolaan, pemanfaatan, dan penilaian.

Berdasarkan permasalahan dan landasan teori yang telah diungkapkan maka pengembangan multimedia permainan interaktif pembelajaran berhitung bagi anak diskalkulia usia prasekolah penting dilakukan untuk pembelajaran berhitung yang 
lebih mudah dan menyenangkan bagi anak diskalkulia usai prasekolah.

Berdasarkan uraian yang telah disampaikan, maka tujuan dari penelitian ini adalah menghasilkan multimedia permainan interaktif pembelajaran berhitung yang layak bagi anak diskalkulia usia prasekolah.

\section{Metode Penelitian}

Penelitian ini merupakan jenis penelitian R \& D (Research and Development). Penelitian ini bertujuan untuk menghasilkan multimedia permainan interaktif pembelajaran berhitung yang layak bagi anak diskalkulia usia prasekolah. Model pengembangan yang digunakan dalam penelitian ini yaitu model pengembangan Alessi \& Trollip.

Model ini terdiri dari tiga fase, yaitu perencanaan, perancangan, dan pengembangan. Pada model Alessi \& Trollip terdapat atribut yang selalu berada dalam setiap fase pengembangan, yaitu standar, evaluasi berkelanjutan, dan manajemen proyek (Alessi \& Trollip, 2001, p. 409).

Pada tahap perencanaan, langkahlangkah yang dilakukan meliputi (1) menentukan ruang lingkup materi yang dilakukan melalui observasi, wawancara, dan kajian teori pembelajaran berhitung bagi anak diskalkulia usia prasekolah, (2) mengidentifikasi karakteristik pengguna, yaitu anak diskalkulia usia prasekolah yang mencakup level kemampuan, usia, level pendidikan, motivasi, dan kemampuan mengunakan komputer, (3) mengidentifikasi kebutuhan program meliputi spesifikasi minimum software dan hardware, (4) menghitung biaya pengembangan, (5) membuat dokumen perencanaan berupa pedoman pengembangan multimedia yang meliputi pengelolaan dana, waktu, dan standar manual proyek, (6) menentukan dan mengumpulkan bahan yang meliputi semua sumber informasi yang dibutuhkan, yaitu sumber yang berhubungan dengan materi pembelajaran, proses pembelajaran, dan aplikasi yang digunakan, dan (7) melakukan brain- storming dengan dokter anak, psikolog, dan terapis anak diskalkulia untuk memperoleh konsep awal multimedia permainan interaktif yang sesuai dengan karakteristik anak diskalkulia usia prasekolah.

Pada tahap perancangan, langkahlangkah yang dilakukan meliputi (1) mengembangkan konsep awal multimedia yang mencakup pengelompokkan materi pembelajaran di dalam multimedia permainan dan menentukan konsep dan aturan permainan, (2) analisis tugas dan isi pembelajaran untuk menghasilkan urutan dan organisasi materi berhitung yang sesuai dengan tahap perkembangan dan karakteristik anak, (3) deskripsi awal program yang dibuat dalam Garis Besar Isi Program Media (GBIPM), (4) membuat flowcharts untuk menampilkan struktur program dari awal hingga akhir permainan dan storyboards untuk menampilkan rancangan tampilan multimedia permainan interaktif yang akan dioperasikan oleh pengguna, dan (5) menyiapkan script untuk audio yang digunakan sebagai instruksi dalam multimedia permainan interaktif.

Pada tahap pengembangan, langkah-langkah yang dilakukan meliputi (1) menulis kode program dengan menggunakan action script 2.0, (2) membuat grafis berupa karakter dalam permainan, objekobjek dalam permainan, dan gambar untuk tombol navigasi, (3) menyatukan komponen-komponen yang sudah dibuat ke dalam software Adobe Flash CS3, kemudia diexport sehingga menghasilkan file dengan ekstensi .swf dan .exe, (4) menyiapkan material yang mendukung meliputi buku manual penggunaan multimedia permainan interaktif, (5) melakukan uji alpha pada dua orang ahli media dan dua orang ahli materi matematika, dan melakukan uji beta pada sembilan orang anak diskalkulia usia prasekolah.

\section{Desain Uji Coba}

Uji coba dilakukan untuk menguji kelayakan produk yang dikembangkan. Uji coba dalam penelitian ini meliputi uji alpha 
dan uji beta. Uji alpha dilakukan oleh dua orang ahli media dan dua orang ahli materi. Penilaian oleh ahli media meliputi aspek rekayasa perangkat lunak, komunikasi visual, dan interaktivitas. Penilaian oleh ahli materi meliputi aspek desain pembelajaran, substansi materi, dan evaluasi pembelajaran.

Validasi oleh ahli media dan ahli materi dilakukan dengan cara mengeksplorasi multimedia permainan interaktif yang sudah dikemas dalam bentuk $C D$, kemudian menilai multimedia berdasarkan aspek-aspek penilaian yang telah tercantum dalam kuesioner validasi ahli media dan ahli materi.

Uji beta dilakukan pada anak diskalkulia usia prasekolah untuk mengetahui respon pengguna terhadap multimedia permainan interaktif. Aspek yang diuji dalam uji beta meliputi kemudahan penggunaan, kejelasan instruksi, dan kesenangan dalam bermain.

Uji beta dilakukan melalui enam langkah berikut (1) memilih anak diskalkulia usia prasekolah yang akan menggunakan multimedia permainan interaktif, (2) menjelaskan prosedur uji beta pada anak diskalkulia usia prasekolah, (3) mencari tahu materi yang telah diketahui anak diskalkulia usia prasekolah, (4) mengamati interaksi anak diskalkulia usia prasekolah dengan multimedia permainan interaktif, (5) menanyakan respon anak diskalkulia usia prasekolah setelah selesai menggunakan multimedia permainan interaktif sesuai dengan aspek-aspek yang terdapat dalam instrumen respon pengguna, dan (6) melakukan revisi multimedia permainan interaktif.

\section{Subjek Uji Coba}

Subjek coba dalam penelitian ini adalah dua orang ahli media untuk menilai kelayakan media dan dua orang ahli materi untuk menilai kelayakan materi untuk melakukan uji alpha dan sembilan anak diskalkulia usia prasekolah dengan rentang usia tiga hingga 6 tahun untuk uji beta.
Jumlah subjek coba yang melakukan uji beta dipilih menggunakan teknik purposive dengan kriteria kemampuan anak diskalkulia usia prasekolah yang baik, sedang, dan kurang untuk mewakili kemampuan anak yang variatif.

\section{Teknik Pengumpulan Data}

Teknik yang digunakan untuk mengumpulkan data dalam penelitian ini meliputi observasi, wawancara, dan kuesioner. Instrumen yang digunakan dalam penelitian ini, yaitu pedoman observasi, pedoman wawancara, kuesioner validasi ahli media, kuesioner validasi ahli materi, dan kuesioner respon pengguna.

Observasi dalam studi pendahuluan dilakukan dengan menggunakan pedoman observasi berupa anecdotal record (catatan anekdot). Observasi dilakukan dengan mencatat perilaku anak diskalkulia usia prasekolah selama melakukan pembelajaran berhitung di Indigrow Child and Development Center. Hasil observasi digunakan untuk memperoleh data mengenai permasalahan dalam pembelajaran berhitung anak diskalkulia usia prasekolah di dalam kelas.

Bentuk wawancara yang digunakan dalam penelitian ini adalah wawancara bebas terpimpin. Wawancara dilakukan dengan menggunakan pedoman wawancara yang memuat pokok-pokok masalah yang akan diteliti. Wawancara dilakukan pada terapis anak diskalkulia di Indigrow Child and Development Center sebagai sumber untuk studi eksploratif. Hasil wawancara digunakan untuk memperoleh data mengenai kesulitan pembelajaran berhitung yang dialami di kelas dan metode yang biasa digunakan dalam pembelajaran berhitung.

Kuesioner digunakan untuk mengetahui kelayakan multimedia permainan interaktif dari ahli media dan ahli materi, serta untuk mengetahui respon pengguna (anak diskalkulia usia prasekolah) terhadap multimedia permainan interaktif.

Kuesioner validasi ahli media diberikan kepada dua orang ahli media untuk mengetahui kelayakan multimedia perma- 
inan interaktif berdasarkan aspek rekayasa perangkat lunak, komunikasi visual, dan interaktivitas. Kuesioner validasi ahli materi berhitung diberikan kepada dua orang ahli materi untuk mengetahui kelayakan multimedia permainan interaktif berdasarkan aspek desain pembelajaran, substansi materi, dan evaluasi pembelajaran.

Kuesioner untuk respon pengguna meliputi aspek kemudahan penggunaan, kejelasan instruksi, dan kesenangan dalam bermain. Kuesioner ini digunakan untuk memperoleh penilaian multimedia permainan interaktif yang layak berdasarkan respon pengguna.

Hasil penilaian dan saran dari kedua ahli media dan kedua ahli materi serta hasil pengamatan dan penilaian respon pengguna dijadikan landasan dalam revisi produk multimedia permainan interaktif.

Teknik Analisis Data

Data yang diperoleh dari instrumen penelitian ini berupa data kualitatif dan kuantitatif. Data kualitatif meliputi saran dan masukan dari ahli media dan ahli materi terhadap multimedia permainan interaktif yang dianalisis menggunakan teknik deskriptif kualitatif Miles \& Huberman. Aktivitas yang dilakukan dalam analisis data, yaitu reduksi data, penyajian data, dan kesimpulan/verifikasi (Sugiyono, 2015, p. 369). Pada tahap reduksi data yang dilakukan meliputi merangkum, memilih hal-hal yang pokok, memfokuskan pada hal-hal yang pokok, mencari tema dan polanya. Langkah selanjutnya penyajian data dilakukan dalam bentuk uraian singkat, bahan, hubungan antarkategori, atau flowchart. Kemudian langkah terakhir yaitu kesimpulan atau verifikasi berupa deskripsi berupa temuan baru yang belum pernah ada. Temuan tersebut yang sebelumnya masih berupa dugaan, kemudian setelah diteliti menjadi jelas.

Data kuantitatif yang merupakan hasil penilaian multimedia permainan interaktif berdasarkan angket validasi ahli media, ahli materi, dan respon pengguna dihitung dengan menjumlahkan keseluruhan jawaban responden kemudian dibagi dengan hasil perkalian skor tertinggi dalam angket dengan jumlah pertanyaan dalam angket dan jumlah responden sehingga diperoleh persentase kelayakan multimedia permainan interaktif (Riduwan, 2013, p. 41). Hasil perhitungan tersebut kemudian diinterpretasikan sesuai dengan kriteria berikut (1) $0 \%-20 \%$ berada dalam kriteria sangat tidak layak, (2) $21 \%-40 \%$ berada dalam kriteria tidak layak, (3) 41\%-60\% berada dalam kriteria cukup layak, (4) 61\%$80 \%$ berada dalam kriteria layak, dan (5) $81 \%-100 \%$ berada dalam kriteria sangat layak.

\section{Hasil Penelitian dan Pembahasan}

Hasil pengembangan dalam penelitian ini, yaitu multimedia permainan interaktif pembelajaran berhitung bagi anak diskalkulia usia prasekolah berupa permainan puzzle dan logika dengan menggunakan software Adobe Flash CS3 yang dikemas dalam bentuk $\mathrm{CD}$ (compact disc) dengan rincian sebagai berikut.

Produk akhir multimedia permainan interaktif pembelajaran berhitung bagi anak diskalkulia usia prasekolah berupa file .exe sehingga pengguna dapat langsung menggunakan produk tanpa perlu melakukan instalasi di dalam komputer. Multimedia permainan interaktif pembelajaran berhitung bagi anak diskalkulia usia prasekolah memiliki dimensi ukuran 1400 × 800 pixels. Produk ini terdiri dari halaman judul, halaman menu utama, halaman area, halaman materi, halaman level, halaman permainan, dan halaman keluar.

Halaman judul dalam multimedia permainan interaktif pembelajaran berhitung bagi anak diskalkulia usia prasekolah memuat informasi mengenai nama permainan, sasaran pengguna, nama pengembang, dan instansi pengembang serta tombol mulai, tombol petunjuk, tombol profil, dan tombol keluar. Berikut ini gambar halaman judul dalam multimedia permainan interaktif. 


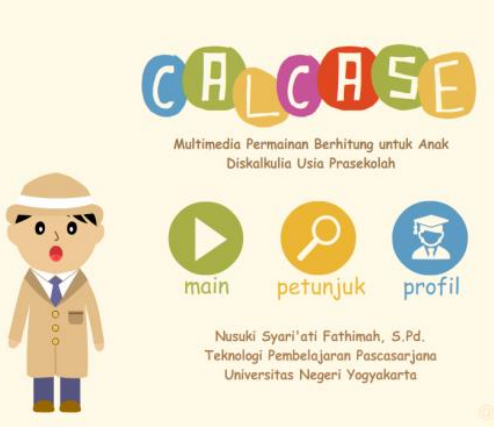

Gambar 1. Halaman Judul

Halaman menu utama memuat tombol home, tombol keluar, tombol area visual-spasial, dan tombol area sekuensial. Pada halaman area visual-spasial, terdapat tombol materi geometri, klasifikasi, dan simbolisasi.

Halaman geometri memuat tombol sub-materi bentuk dan sub-materi letak, serta tombol home, kembali, dan keluar. Pada halaman materi bentuk dan letak terdapat tombol level 1-3, tombol kembali, tombol home, dan tombol keluar.

Halaman bentuk level 1-3 memuat gambar pintu dengan variasi bentuk geometri di depannya, teks level permainan, teks jumlah koin yang sudah didapatkan pengguna, tombol kembali, tombol home, tombol keluar, dan tombol simpan. Pada halaman ini pengguna diberi instruksi untuk memilih pintu dengan bentuk geometri yang sesuai dengan yang disebutkan (lingkaran, persegi, segitiga, atau segilima). Berikut ini gambar halaman bentuk dalam multimedia permainan interaktif.

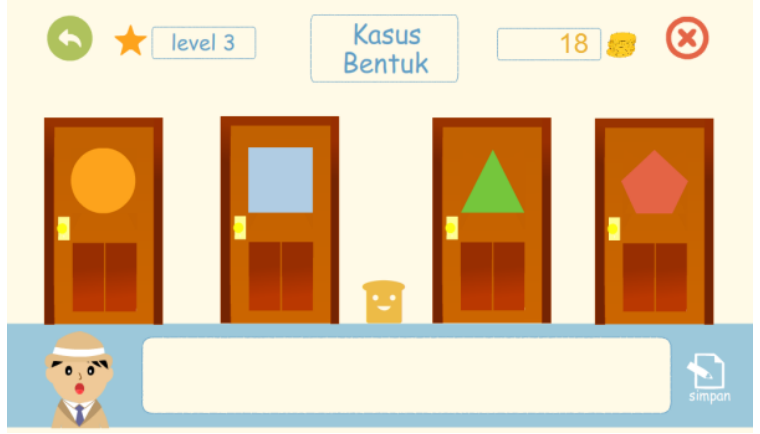

Gambar 2. Halaman Bentuk

Halaman letak level 1-3 memuat gambar beberapa pintu dengan berbagai posisi, teks level permainan, teks jumlah koin yang sudah didapatkan pengguna, tombol kembali, tombol home, tombol keluar, dan tombol simpan. Pada halaman ini pengguna diberi instruksi untuk memilih pintu sesuai dengan letak yang disebutkan (kanan, kiri, tengah, atas, atau bawah). Berikut ini gambar halaman letak dalam multimedia permainan interaktif.

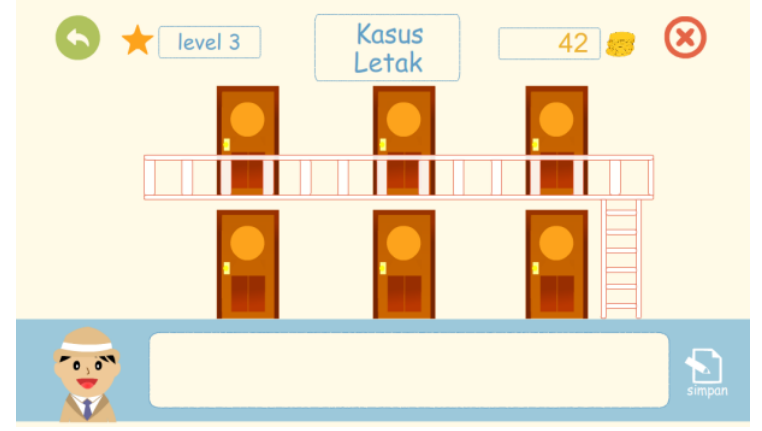

Gambar 3. Halaman Letak

Halaman klasifikasi memuat tombol level 1-7, tombol kembali, tombol home, dan tombol keluar. Pada halaman klasifikasi level 1-7 memuat gambar bermacam variasi bentuk geometri yang berbeda bentuk, warna, dan/atau ukuran dan gambar kotak untuk menyimpan benda sesuai kelompoknya. Pada halaman ini pengguna diberi instruksi untuk memasukkan benda ke dalam kotak sesuai dengan bentuk, warna, dan/atau ukurannya. Berikut ini gambar halaman klasifikasi dalam multimedia permainan interaktif.

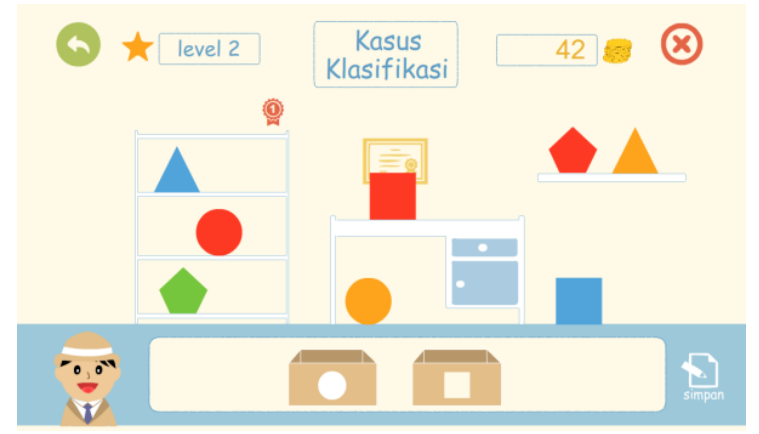

Gambar 4. Halaman Klasifikasi

Halaman simbolisasi memuat tombol sub-materi nama, simbol, dan jumlah, tombol kembali, tombol home, dan tombol keluar. Pada masing-masing halaman sub- 
materi nama, simbol, dan jumlah terdapat tombol level 1-3.

Halaman sub-materi nama level 1-3 memuat gambar dua kotak yang berisi jumlah benda yang berbeda, tombol kembali, tombol home, tombol keluar, dan tombol simpan. Pada halaman ini pengguna diberi instruksi untuk memilih kotak yang sesuai dengan jumlah benda yang disebutkan. Berikut ini gambar halaman nama dalam multimedia permainan interaktif.

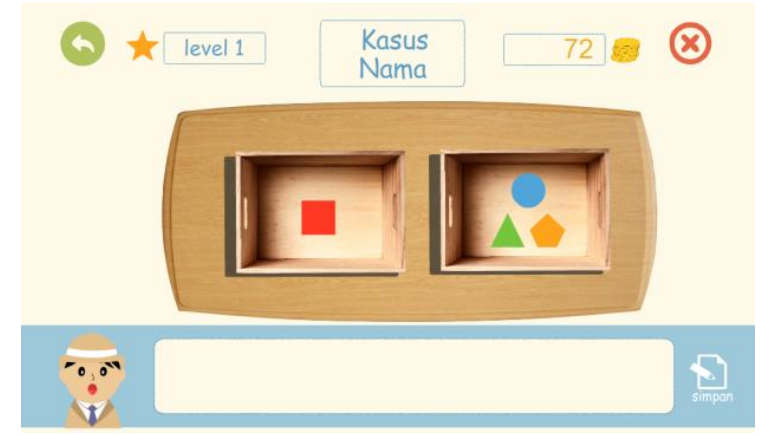

Gambar 5. Halaman Nama

Halaman simbol level 1-3 memuat gambar loker dengan lambang bilangan yang disusun secara acak, tombol kembali, tombol home, tombol keluar, dan tombol simpan. Pada halaman ini pengguna diberi instruksi untuk memilih lambang angka yang sesuai dengan nama angka yang disebutkan. Berikut ini gambar halaman simbol dalam multimedia permainan interaktif.

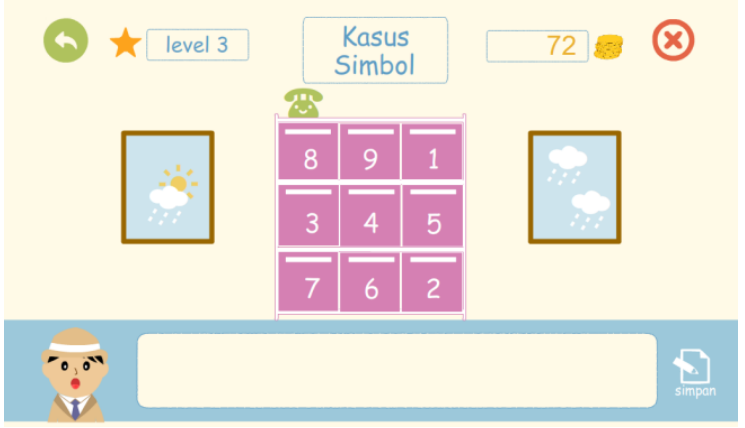

Gambar 6. Halaman Simbol

Halaman lambang level 1-3 memuat gambar kotak berisi sejumlah benda, gambar 5 lambang bilangan yang disusun secara acak, tombol kembali, tombol home, tombol keluar, dan tombol simpan. Pada halaman ini pengguna diberi instruksi untuk memi- lih salah satu lambang bilangan yang sesuai dengan jumlah benda yang ada di dalam kotak. Berikut ini gambar halaman lambang dalam multimedia permainan interaktif.

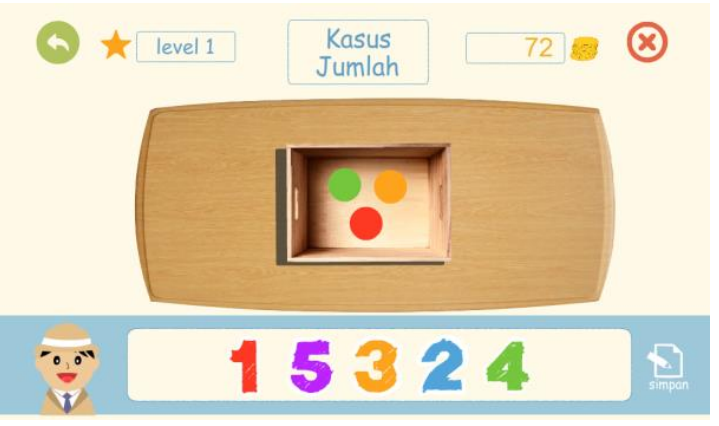

Gambar 7. Halaman Lambang

Pada halaman area sekuensial terdapat tombol materi prosedur, korespondensi, dan bilangan. Pada setiap halaman area terdapat tombol kembali, home, dan keluar.

Halaman prosedur memuat tombol sub-materi aktivitas dan gambar, tombol kembali, tombol home, dan tombol keluar. Pada masing-masing halaman sub-materi terdapat tombol level 1-3.

Halaman aktivitas level 1-3 memuat urutan gambar aktivitas sehari-hari yang disusun secara acak, gambar papan jadwal, tombol kembali, tombol home, tombol keluar, dan tombol simpan. Pada halaman ini pengguna diberi instruksi untuk menempatkan gambar aktivitas ke dalam papan sesuai dengan urutan kegiatannya. Berikut ini gambar halaman aktivitas dalam multimedia permainan interaktif.

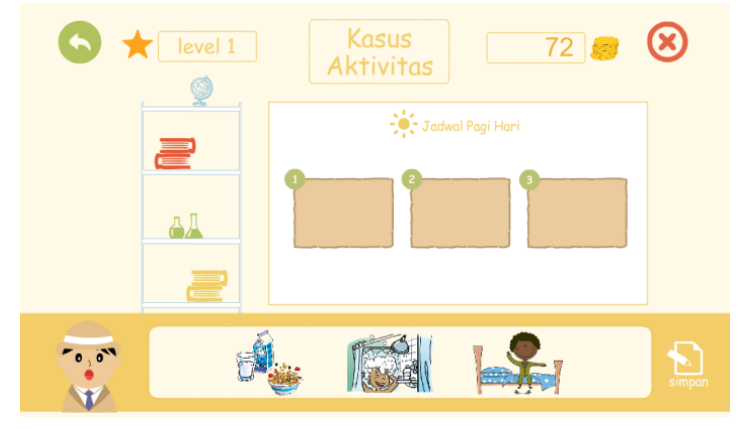

Gambar 8. Halaman Aktivitas

Halaman gambar level 1-3 memuat potongan gambar yang disusun secara acak, papan puzzle, tombol kembali, tombol home, tombol keluar, dan tombol simpan. Pada 
halaman ini pengguna diberi instruksi untuk menempatkan gambar ke dalam papan sesuai dengan urutannya hingga menjadi gambar utuh. Berikut ini gambar halaman gambar dalam multimedia permainan interaktif.

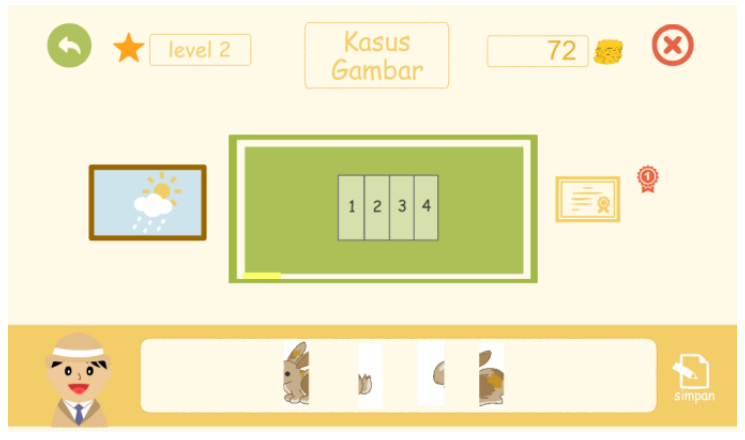

Gambar 9. Halaman Gambar

Halaman korespondensi memuat tombol level 1-3, tombol kembali, tombol home, dan tombol keluar. Halaman korespondensi level 1-3 memuat gambar berupa beberapa benda dan gambar kotak untuk menyimpan benda. Pada halaman ini pengguna diberi instruksi untuk memasukkan benda satu per satu ke dalam kotak sesuai dengan jumlah yang disebutkan. Berikut ini gambar halaman korespondensi dalam multimedia permainan interaktif.

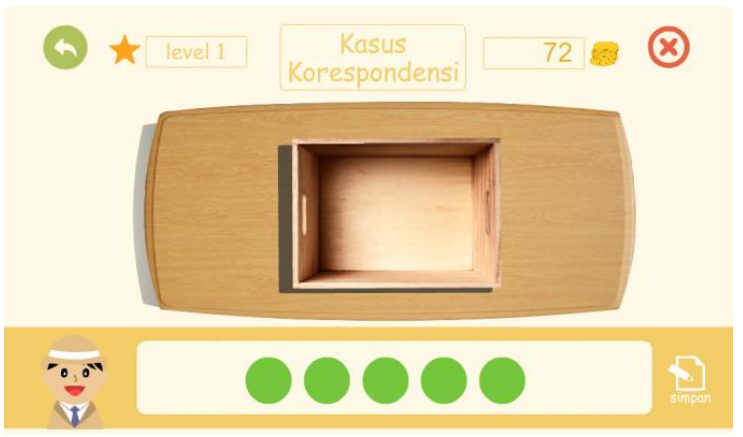

Gambar 10. Halaman Korespondensi

Halaman bilangan memuat tombol level 1-3, tombol kembali, tombol home, dan tombol keluar. Halaman bilangan level 1-3 memuat gambar benda dengan lambang bilangan di depannya. Pada halaman ini pengguna diberi instruksi untuk menyusun bilangan sesuai dengan urutannya. Berikut ini gambar halaman bilangan dalam multimedia permainan interaktif.

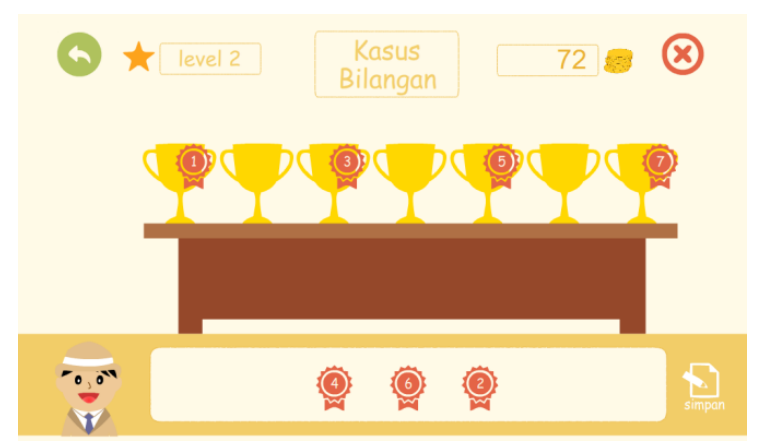

Gambar 11. Halaman Bilangan

Halaman keluar dari permainan memuat tombol ya untuk keluar dari permainan dan tombol tidak untuk kembali bermain.

Produk multimedia permainan interaktif pembelajaran berhitung bagi anak diskalkulia usia prasekolah ini disertai dengan buku petunjuk penggunaan yang berisi: 1) spesifikasi program memuat identitas program dan persyaratan minimal sistem untuk mengoperasikan multimedia permainan interaktif, 2) petunjuk penggunaan memuat penjelasan untuk memulai penggunaan multimedia permainan interaktif dan penggunaan tombol navigasi, 3) cara bermain memuat penjelasan mengenai cara melakukan permainan di setiap area permainan, dan 4) profil pengembang memuat penjelasan mengenai identitas pengembang multimedia permainan interaktif.

Produk multimedia permainan interaktif telah dikembangkan sesuai dengan tahap-tahap pengembangan multimedia pembelajaran Alessi \& Trollip yang meliputi perencanaan, desain, dan pengembangan yang dilengkapi dengan atribut dalam setiap tahap pengembangan, yaitu standar, evaluasi berkelanjutan, dan manajemen proyek. Jenis permainan dalam multimedia permainan interaktif yang dikembangkan termasuk dalam permainan puzzle dan logika karena dalam permainan ini anak harus mampu menggunakan pemecahan masalah logis untuk berhasil menyelesaikan permainan. Proses pengembangan multimedia permainan interaktif ini sesuai dengan teori pengembangan multimedia menurut Alessi \& Trollip (2001, p. 411). 
Hasil dari tahap perencanaan yang diperoleh melalui observasi, wawancara, dan studi pustaka, ruang lingkup materi dalam produk multimedia dikelompokkan berdasarkan area potensial kesulitan anak diskalkulia, yaitu area visual-spasial dan area sekuensial sehingga multimedia dapat mengakomodasi kebutuhan anak. Area visual-spasial terdiri dari materi geometri, klasifikasi, dan simbolisasi. Pada materi geometri, anak diberi instruksi untuk memilih bentuk lingkaran, persegi, segitiga, atau segilima sesuai dengan instruksi yang diberikan dan memilih posisi kanan, kiri, tengah, atas, atau bawah sesuai instruksi yang diberikan. Materi tersebut sesuai dengan perkembangan anak usia prasekolah yaitu mengenal konsep bentuk dan letak. Pada materi klasifikasi, anak diberi instruksi untuk memasukkan benda ke dalam kotak berdasarkan bentuk, warna, dan/atau ukurannya. Materi tersebut sesuai dengan tingkat pencapaian perkembangan anak prasekolah yaitu mengklasifikasikan benda berdasarkan bentuk, warna, atau ukuran dan mengelompokkan benda ke dalam kelompok yang sama dengan 2-3 variasi. Pada materi simbolisasi, anak diberi instruksi untuk mencocokkan nama bilangan dengan lambang bilangannya, nama bilangan dengan jumlah bilangannya, dan lambang bilangan dengan jumlah bilangannya. Materi tersebut sesuai dengan tingkat pencapaian perkembangan anak prasekolah yaitu mengenal konsep bilangan dan lambang bilangan.

Area sekuensial terdiri dari materi algoritma, korespondensi, dan bilangan. Pada materi algoritma, anak diberi instruksi untuk mengurutkan aktivitas sehari-hari dan menyusun potongan gambar. Materi tersebut sesuai dengan tingkat pencapaian perkembangan anak prasekolah yaitu mengenal pola. Pada materi korespondensi satu-satu, anak diberi instruksi untuk memasukkan benda ke dalam kotak sesuai dengan jumlah yang diminta. Materi tersebut sesuai dengan tingkat pencapaian perkembangan anak prasekolah yaitu dapat membilang banyak benda dari satu sampai sepuluh. Pada materi bilangan, anak diberi in- struksi untuk menyusun angka sesuai dengan urutannya. Materi tersebut sesuai dengan tingkat pencapaian perkembangan anak prasekolah yaitu dapat menyebutkan lambang bilangan dari satu sampai sepuluh. Penyajian materi dalam multimedia permainan interaktif sesuai dengan teori perkembangan kemampuan berhitung anak usia prasekolah menurut Permendiknas No. 58 Tahun 2009 dan area potensial kesulitan belajar berhitung (diskalkulia) menurut Chinn \& Ashcroft (2007, p. 17).

Setiap materi permainan disajikan bertahap dalam beberapa level agar anak belajar dimulai dari yang mudah kemudian semakin sulit. Selain itu, setiap anak berhasil menyelesaikan instruksi anak akan mendapat koin dan tersedia umpan balik berupa suara yang dapat menyemangati anak. Jenis permainan dalam masing-masing materi pun bervariasi sehingga anak akan merasa senang dan tidak mudah bosan ketika bermain. Hal tersebut sesuai dengan teori prinsip-prinsip permainan untuk anak usia prasekolah menurut Triharso (2013, p. 47).

Tujuan dalam permainan geometri adalah anak dapat menemukan bentuk dan posisi benda sesuai dengan instruksi yang diberikan. Peraturan dalam permainan geometri adalah anak akan mendapatkan koin jika memilih bentuk atau posisi benda yang sesuai, tetapi koin akan dikurangi jika anak memilih bentuk atau posisi benda yang tidak tepat. Tantangan dalam permainan geometri ini yaitu anak harus memilih bentuk atau posisi yang tepat dari pilihan bentuk atau posisi yang tersedia. Fantasi anak dilibatkan dalam menentukan bentuk yang tepat sesuai dengan instruksi.

Tujuan dalam permainan klasifikasi adalah anak dapat mengelompokkan benda berdasarkan warna, jenis, dan/atau ukurannya. Peraturan dalam permainan klasifikasi adalah anak mendapatkan koin setiap memasukkan benda ke dalam kelompoknya sesuai instruksi, tetapi koin akan dikurangi jika anak memasukkan benda yang tidak sesuai dengan kelompoknya. Tantangan dalam permainan klasifikasi ini yaitu anak harus memilih benda sesuai krite- 
rianya diantara berbagai macam benda yang bervariasi. Fantasi anak dilibatkan dalam menemukan benda yang tepat sesuai dengan instruksi.

Tujuan dalam permainan simbolisasi adalah anak dapat mengenal konsep bilangan dan lambang bilangan. Peraturan dalam permainan simbolisasi adalah anak mendapatkan koin setiap berhasil mencocokkan nama bilangan dengan lambang bilangannya, nama bilangan dengan jumlah bilangannya, dan lambang bilangan dengan jumlah bilangannya, tetapi koin akan dikurangi jika anak mencocokkan dengan tidak tepat. Tantangan dalam permainan ini yaitu lambang bilangan dan kelompok jumlah bilangan yang bervariasi untuk mengecoh anak. Fantasi anak dilibatkan dalam menentukan lambang bilangan atau jumlah bilangan yang tepat sesuai instruksi.

Tujuan dalam permainan algoritma adalah anak mampu menyusun urutan langkah dalam melakukan kegiatan seharihari atau menyusun urutan potongan gambar sehingga menjadi gambar yang utuh. Peraturan dalam permainan ini adalah anak akan mendapatkan koin ketika menempatkan potongan kegiatan atau gambar di urutan yang tepat, tetapi koin akan dikurangi ketika menempatkan potongan kegiatan atau gambar di urutan yang salah. Tantangan dalam permainan ini yaitu setiap potongan disusun secara acak, sehingga anak harus memikirkan baik-baik urutan yang tepat untuk setiap kegiatan atau potongan gambar. Fantasi anak dilibatkan dalam menentukan urutan suatu kegiatan dan membayangkan potongan gambar yang utuh.

Tujuan dalam permainan korespondensi adalah anak mampu membilang sesuai dengan jumlah bendanya. Peraturan dalam permainan ini adalah anak akan mendapatkan koin ketika anak berhasil menempatkan benda ke dalam kotak sesuai jumlah yang diinstruksikan. Tantangan dalam permainan ini yaitu anak harus memasukkan benda ke dalam kotak sesuai dengan jumlah yang diinstruksikan. Fantasi anak dilibatkan dalam membayangkan jumlah yang diminta kemudian menyesuai- kannya dengan jumlah benda yang dimasukkan ke dalam kotak.

Tujuan dalam permainan bilangan adalah anak mampu menyusun bilangan satu sampai sepuluh sesuai dengan urutannya. Peraturan dalam permainan bilangan adalah anak akan mendapatkan koin jika berhasil menempatkan suatu bilangan di urutan yang tepat, tetapi koin akan dikurangi jika anak menempatkan suatu bilangan di urutan yang salah. Tantangan dalam permainan ini yaitu anak harus menentukan urutan suatu bilangan diantara susunan bilangan yang tersedia. Fantasi anak dilibatkan dalam membayangkan susunan bilangan yang tepat.

Multimedia permainan ini melibatkan anak bermain dengan aman karena jika anak tidak menyelesaikan instruksi dengan tepat anak hanya mendapat pengurangan koin. Hiburan dalam permainan ini diberikan dengan koin yang diberikan setiap anak berhasil menyelesaikan instruksi dan umpan balik berupa suara tepuk tangan ketika anak berhasil menyelesaikan satu level permainan yang dapat menyemangati anak untuk terus bermain. Penerapan faktor-faktor tersebut sesuai dengan teori faktor-faktor dalam multimedia menurut Alessi \& Trollip (2001, p. 277)

Pemberian koin setiap anak berhasil menyelesaikan instruksi merupakan penguatan positif, sementara pengurangan koin ketika anak belum berhasil menyelesaikan permainan sesuai instruksi merupakan penguatan negatif. Kedua hal tersebut merupakan penerapan dari teori belajar behavioristik. Menurut teori kognitif, unsur terpenting dalam belajar adalah pengetahuan yang dimiliki individu sesuai dengan situasi belajarnya, sehingga materi yang disajikan dalam multimedia disesuaikan dengan tahap perkembangan anak prasekolah yang dikelompokkan sesuai dengan area potensial kesulitan anak diskalkulia. Melalui multimedia, anak dapat belajar dengan membangun sendiri pengetahuannya melalui pengalamannya dan anak dapat berpartisipasi aktif dalam proses pembelajaran 
mereka. Hal ini sesuai dengan pemahaman teori belajar konstruktivistik.

Kelayakan produk multimedia permainan interaktif ini dinilai berdasarkan uji alpha berupa validasi oleh ahli media dan ahli materi dan uji beta pada anak diskalkulia usia prasekolah. Pada uji alpha, hasil validasi oleh ahli media diperoleh persentase kelayakan $88,33 \%$ dengan rerata penilaian 3,44 untuk aspek rekayasa perangkat lunak, 3,54 untuk aspek komunikasi visual, dan 3,6 untuk aspek interaktivitas. Aspekaspek tersebut tidak terlepas dari teori multimedia permainan dan teori pengembangan multimedia menurut Aless \& Trollip (2001, p. 411) sehingga multimedia yang dikembangkan dapat sesuai dengan karakteristik peserta didik dan memudahkan peserta didik dalam mengoperasikan multimedia. Hasil penilaian masing-masing ahli media dalam tiap aspek penilaian disajikan dalam diagram berikut.

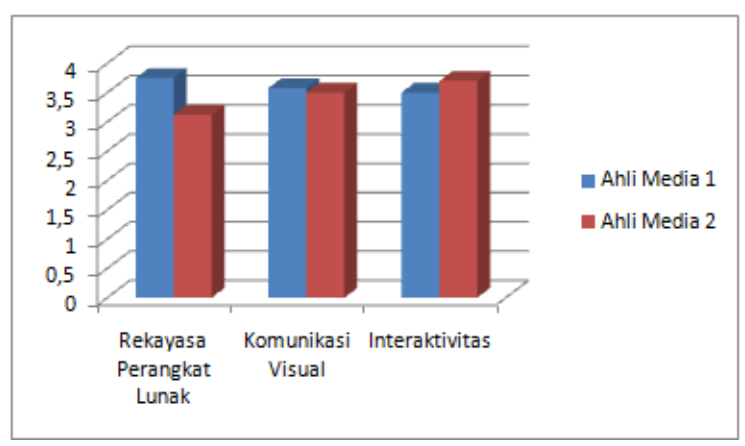

Gambar 12. Diagram Penilaian Ahli Media

Hasil validasi oleh ahli materi diperoleh persentase kelayakan $91,67 \%$ dengan rerata penilaian 3,6 untuk aspek desain pembelajaran, 3,75 untuk aspek substansi materi, dan 3,5 untuk aspek evaluasi pembelajaran. Aspek desain pembelajaran tidak terlepas dari teori karakteristik anak diskalkulia usia prasekolah dalam menentukan strategi yang tepat untuk dapat mengakomodasi kebutuhan anak diskalkulia. Aspek substansi materi tidak terlepas dari tahap perkembangan pencapaian anak prasekolah sesuai dengan Permendiknas Nomor 58 Tahun 2008 Pasal 1(2) (Menteri Pendidikan Nasional Republik Indonesia, 2009) dan teori pembelajaran berhitung bagi anak diskalkulia, sehingga materi dalam multimedia tidak terlalu mudah atau terlalu sulit bagi anak serta sesuai dengan karakteristik anak diskalkulia. Hasil penilaian masing-masing ahli materi dalam tiap aspek penilaian disajikan dalam diagram berikut.

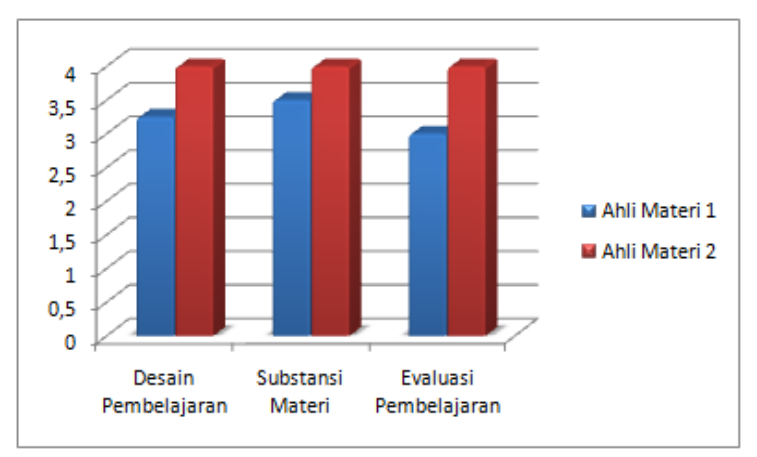

Gambar 13. Diagram Penilaian Ahli Materi

Pada uji beta, hasil validasi oleh pengguna diperoleh persentase kelayakan $85,18 \%$ dengan rerata penilaian $77,78 \%$ untuk aspek kemudahan penggunaan, 77,78\% untuk aspek kejelasan instruksi, dan 100\% untuk aspek kesenangan dalam bermain. Multimedia permainan ini mendapatkan persentase kelayakan $100 \%$ untuk kesenangan dalam bermain, hal ini tidak terlepas dari penerapan prinsip-prinsip permainan matematika bagi anak usia dini. Hasil penilaian respon pengguna disajikan dalam diagram berikut.

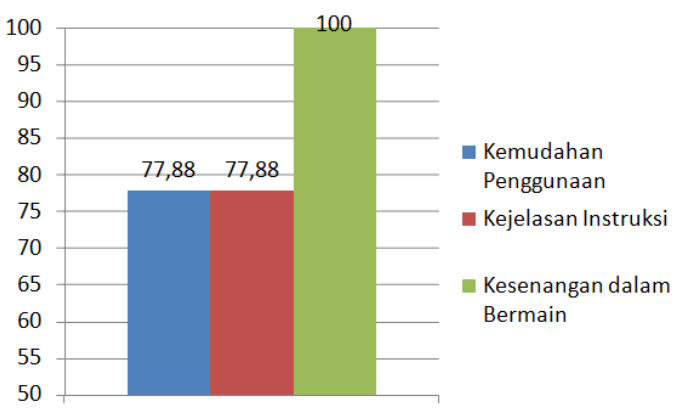

Gambar 14. Hasil Penilaian Respon Pengguna

Berdasarkan tahap uji coba tersebut, multimedia permainan interaktif layak digunakan sebagai media pembelajaran berhitung bagi anak diskalkulia usia prasekolah baik dari validasi media, validasi ma- 
teri, maupun respon pengguna. Kelayakan produk multimedia yang dikembangkan ini sesuai dengan toeri penilaian multimedia permainan interaktif menurut Munadi, (2013) dan Alessi \& Trollip (2001, p. 414).

Multimedia permainan interaktif ini memiliki beberapa kelebihan, yaitu (1) penyajian materi dalam multimedia ini mengakomodasi kebutuhan anak diskalkulia dalam area visual, spasial, dan sekuensial, (2) multimedia bersifat interaktif sehingga dapat menarik perhatian anak dan melibatkan anak secara aktif, (3) multimedia berbentuk file .exe sehingga mudah digunakan, (4) multimedia berbentuk permainan ini dapat membantu anak diskalkulia belajar dengan menyenangkan.

Adapun kekurangan dari multimedia permainan ini, yaitu (1) multimedia permainan belum dikembangkan untuk mengakomodasi kebutuhan anak diskalkulia dalam area potensial yang lain, yaitu kebingungan arah, memori, kecepatan kerja, dan bahasa matematika, (2) multimedia permainan belum memiliki unsur kompetisi yang dapat meningkatkan motivasi anak diskalkulia, dan (3) penyajian materi dalam multimedia belum dikelompokkan sesuai usia masing-masing anak usia prasekolah.

\section{Simpulan}

Berdasarkan hasil penelitian dan pembahasan yang telah disampaikan, maka dari penelitian ini dapat disimpulkan sebagai berikut. Penelitian ini menghasilkan multimedia permainan interaktif pembelajaran berhitung yang layak bagi anak diskalkulia usia prasekolah berupa permainan logika dan puzzle yang dikemas dalam bentuk CD (compact disc).

Multimedia permainan interaktif pembelajaran berhitung bagi anak diskalkulia usia prasekolah dinilai sangat layak. Kelayakan tersebut dikarenakan dalam multimedia mengakomodasi materi melalui permainan dalam area visual, spasial, dan sekuensial. Hal tersebut juga dapat dilihat berdasarkan hasil uji alpha dengan per- sentase kelayakan dari ahli media sebesar $88,33 \%$ dan persentase kelayakan dari ahli materi sebesar 91,6\% serta berdasarkan hasil uji beta dengan persentase kelayakan dari respon pengguna sebesar $85,18 \%$.

Berdarasakan simpulan tersebut, dapat disampaikan saran sebagi berikut. Pemanfaatan multimedia permainan interaktif ini sebaiknya digunakan sesuai dengan spesifikasi minimal yang disajikan dalam buku petunjuk penggunaan multimedia permainan interaktif. Multimedia dapat digunakan oleh guru sebagai alternatif pembelajaran bagi anak diskalkulia usia prasekolah untuk mengakomodasi kebutuhan anak. Saat menggunakan multimedia sebaiknya anak didampingi oleh orang dewasa agar anak dapat menyimak instruksi dengan lebih baik.

\section{Daftar Pustaka}

Abdulhak, I., \& Darmawan, D. (2013). Teknologi Pendidikan. Bandung: PT Remaja Rosdakarya.

Alessi, S. M., \& Trollip, S. P. (2001). Multimedia for learning: methods and development (3rd ed.). Boston: Allyn and Bacon.

Bardi, B., \& Jailani, J. (2015).

Pengembangan multimedia berbasis komputer untuk pembelajaran matematika bagi siswa SMA. Jurnal Inovasi Teknologi Pendidikan, 2(1), 4963.

https:// doi.org/10.21831/tp.v2i1.520 3

Boyse, K. (2012). Learning disabilities.

Casey, L. B., Reeves, K. C., \& Conner, E. C. (2012). Using technology in the world of play. Information Science Reference.

Chinn, S., \& Ashcroft, R. (2007). Mathematics for dyslexics including dyscalculia (3rd ed.). West Sussex: John Willey \& Sons, Ltd.

Heruman. (2013). Model pembelajaran 
matematika di sekolah dasar. Bandung: PT Remaja Rosdakarya.

Januszewski, A., \& Molenda, M. (2008). Educational technology: a definition with commentary. New York: Lawrence Erlbaum Associates.

Menteri Pendidikan Nasional Republik Indonesia. Peraturan Menteri Pendidikan Nasional Republik Indonesia Nomor 58 Tahun 2009 tentang Standar Pendidikan Anak Usia Dini (2009).

Munadi, Y. (2013). Media pembelajaran sebuah pendekatan baru. Jakarta: Referensi.

Mutlu, Y., \& Akgun, L. (2017). The effects of computer assisted instruction materials on approxiomate number skills of student with dyscalculia. TOJET: The Turkish Online Journal of Educational Technology, 16(2), 119-136.

Powell, A., \& Ray, B. (2012). Supporting mathematics for young children through technology. Hershey: Information Science Reference.

Putra, L. D., \& Ishartiwi, I. (2015). Pengembangan multimedia pembelajaran interaktif mengenal angka dan huruf untuk anak usia dini. Jurnal Inovasi Teknologi Pendidikan, 2(2), 169-178. https://doi.org/10.21831/tp.v2i2.760 7

Reddi, U. V, \& Mishra, S. (2003). Educational multimedia: A handbook for teacher-developers. New Delhi:

\section{CEMCA.}

Riduwan. (2013). Skala pengukuran variabelvariabel penelitian. Bandung: Alfabeta.

Smaldino, S. E., Lowther, D. . L., \& Russel, J. D. (2014). Instructional technology and media for learning. Essex: Pearson Education Limited.

Smith, D. D., \& Luckasson, R. (1995). Introduction to special eduactoin teaching in an age of challenge. Boston: Allyn and Bacon.

Subini, N. (2011). Mengatasi kesulitan belajar pada anak. Yogyakarta: Javalitera.

Sugiyono. (2015). Metode penelitian dan pengembangan. Bandung: Alfabeta.

Triharso, A. (2013). Permainan kreatif $\mathcal{E}$ edukatif untuk anak usia dini. Yogyakarta: Penerbit Andi.

Widyatmojo, G., \& Muhtadi, A. (2017). Pengembangan multimedia pembelajaran interaktif berbentuk game untuk menstimulasi aspek kognitif dan bahasa. Jurnal Inovasi Teknologi Pendidikan, 4(1), 38. https:// doi.org/10.21831/jitp.v4i1.10 194

Wijaya, Y. P. (2014). Pengertian multimedia interaktif. Retrieved August 31, 2015, from https:/ / yogapermanawijaya.wordpre ss.com/2014/04/24/pengertianmultimedia-interaktif-2/

Wood, D. (2009). Kiat mengatasi gangguan belajar. Yogyakarta: Kata Hati. 